\title{
Lifelong Learning in Artistic Context Mediated by Advanced Technologies
}

\author{
Mirella Ferrari \\ Department of Human Sciences, University of Milano-Bicocca, Italy
}

Copyright $\bigcirc 2016$ by authors, all rights reserved. Authors agree that this article remains permanently open access under the terms of the Creative Commons Attribution License 4.0 International License

\begin{abstract}
This research starts by analysing the current state of artistic heritage in Italy and studying some examples in Europe: we try to investigate the scope of non-formal learning in artistic context, mediated by advanced technology. The framework within which we have placed our investigation is that of lifelong learning and lifedeep learning. The research considers a number of excellent Italian and European museums in context of lifelong learning activities and offers a software prototype that has been built specifically for studying the artistic experience, namely M_ART about the Basilica of St. Ambrogio in Milan. The quantitative/qualitative methods adopted analysed about 400 subjects. The goal pursued, in logic of hybridization of knowledge in scientific and humanistic vocation, was to consider the application of advanced technologies in non-formal settings, with particular reference to the artistic sphere. The experience/investigation was carried out by examining 400 subjects in 3 exploratory phases: on-site observation, questionnaires and focus groups. From the analysis of qualitative and quantitative data it emerges that there is a need to redefine the role of a museum in order for it to move beyond its traditional conservative role in favour of educational activities dedicated not only to the very young, but also to adults; moreover, it is necessary to offer services that use innovative technological support and keep up with the fast paced changes in technology that affect us on a daily basis. In the Italian context, but also in a European one, a fragmented picture emerges: educational activities geared to adults in the world of art are rarely present in museums and, when they are, tend to mostly have the function of providing entertainment or a mere itemisation of the collection on display. It presents a picture in which lifedeep learning and lifelong learning are still marginal compared to learning by adults in a museum context.
\end{abstract}

Keywords Lifelong Learning, Lifedeep Learning, Non-formal Learning, Museum, Mobile Learning

\section{Introduction}

Availability in Italy and Europe of museum workshops and activities mediated by advanced technologies: some examples.

This research is conceived as a scientific experience to help us examine new methodologies of permanent learning and new approaches to learning mediated by advanced technologies in the museum environment. Firstly however, a few fundamental premises are called for in order to set the scene.

An analysis of the Lifelong Learning (henceforth LLL) Programme, pinpoints three key priorities to be addressed by all European countries, namely the need to:

1) increase human resources;

2) create employment opportunities;

3) promote economic growth and development.

To these we must add a number of strategic objectives, in line with the goals set out in the Bologna process for 2020.

1) increase the number of graduates;

2) improve the quality and importance of teaching and learning;

3) promote mobility;

4) strengthen the triangle of knowledge (education, research, innovation)

5) strengthen LLL;

6) promote social cohesion;

7) include entrepreneurial experiences at all levels of education and training [42].

Projections drawn up by the Organization for Economic Cooperation and Development (OECD) state that by 2020 at least $40 \%$ of the population should have a higher level of education and that at least $14 \%$ of the population should be taking part in lifelong learning practices [26]. These estimates are based on quantitative analyses that are systematically carried out on the subject of formal and informal LLL in schools, universities and non-profit associations that offer LLL opportunities for adults.

Given these premises and by examining scientific literature [16, 36, 37] which highlights the importance of LLL for social inclusion, active citizenship and personal development, a picture emerges which on the one hand considers and defines specific and ambitious goals, yet on 
the other struggles to reach them, particularly in Italy and in certain other EU countries.

In addition to this uneven scenario, in which certain EU countries are in line with these objectives and others lack any kind of network or association that provides Adult Education (henceforth $\mathrm{AE}$ ), there are few available case studies and little scientific literature that examines the relationship between art and AE [31]. Despite this somewhat complex situation, there are some signs that Italy is taking small steps towards meeting the 2020 goals, as required by the EU.

These objectives become even more critical in a stagnant economy such as that which has affected Italy in recent years. Let us for instance consider how crucial it is in a 'knowledge economy' [8] for the workforce to acquire know-how and skills that are great enough and flexible enough to be competitive, how important it is to be able to 'access' knowledge and skills [26] in order to maintain an active role in the labour market [7], and how vital it is to be able to acquire these in ways and times that suit the individual. Let us consider OCSE data, since these are currently the only figures available to us that examine the relationship between LLL and continuous learning in a museum context. It is within this framework that our research takes place.

Italy, unfortunately, has marginal positions in the OCSE tables. However, despite the limited signs of growth in LLL opportunities, there does seem to be an encouraging attitude towards increasing the debate and discussion on LLL. We should also remember that Italy is $6^{\text {th }}$ out of the 41 countries analysed by the OCSE in terms of number of individuals pursuing higher education - including graduate and post-graduate courses - with $15.71 \%$ compared to an international average of $32.63 \%$. The highest levels of participation are seen in Japan, Canada and Russia with, respectively, $46 \%, 52 \%$ and $53 \%$. On a national level, the record goes to the northern regions of Italy where Lombardy was leading in 2013 with 369,000 individuals pursuing higher education, post-graduate courses or courses aimed at continuing professional development.

The educational options analysed by the OECD [25] include those carried out in non-formal contexts, which are of primary importance to our investigation. We will focus particularly on learning opportunities in museum contexts. We will look at what LLL opportunities are provided to adults in museums in Italy.

An initial analysis reveals a two-sided reality: on the one hand we have museums that are particularly open to exploring new possibilities, on the other are museums that focus solely on the preservation of their artistic heritage and offer no activities beyond the traditional guided tour.

Alas, these closely linked yet contrasting realities do not promote experimentation of non-conventional learning methods aimed at producing scientific quality and, even less so, do they create opportunities for the classification and sharing of results. Exceptions include the many experiments undertaken by the Uffizi Museum in Florence, coordinated by Maria Fossati Todorow, those held by the Laboratorio del
Loggiato at the Brera art gallery in Milan, directed by Renate Eco [14] and the Della Pergola experiences offered at the Galleria Borghese in Rome. Credit must be given to the Poldi Pezzoli Museum for the commitment it has shown, since the 1970s, to creating thematic tours for visitors and in particular for primary school pupils. Among other notable examples we should also remember the Museum of Modern and Contemporary Art of Trento and Rovereto (MART) and the GAM in Turin [5], the two, out of a handful of museums, that regularly promote their collections and activities by means of frequent printed material as well as through workshops, seminars and learning-by-doing events for adults [23]. The GAM museum in Turin was conceived as a source of knowledge, an environment to return to over and over again in order to discover and learn about art [11,2]. Although advanced technologies $[27,28]$ for learning about art are present in some of the more significant GAM workshop programmes they are not however integral part of all its mediated learning

The use of technologies for continuous learning in museum environments is, regrettably, not highlighted in any of these commendable activities. In fact, aside from scientific coding efforts undertaken by Dewey, Herbert Read [29], Arno Stern [35] and Munari [24], there do not seem to be any obvious trends that can be linked to a clear, methodical and scientific approach.

We questioned the reasons for so many missed opportunities: opportunities for using a museum environment not solely as an aesthetically pleasing place of leisure, but also as learning environment. Indeed through art we can learn about our country's history; we can acquire knowledge of our cultural traditions; rediscover our origins; appraise the past. These are the most obvious learning opportunities associated with a museum environment, but there are many others that can turn a museum into a "socially interactive" environment. Aperitif evenings at the Museo Reale in Milan, for instance, or musical events such as those promoted from time to time by different Italian city museums. Moreover, a museum can help refresh previously acquired information by means of sensorial experiences such as those provided by the Barbaro events at the GAM museum in Turin [5].

Perhaps one of the primary reasons for these missed opportunities can be found in the cultural approach, in the fact that the traditional museum tends to be linked to historical and artistic content and to the realms of archive and conservation, rather than to the social and psychological sciences with which we typically associate LLL. Another reason lies in the complex bureaucratic procedures that must be followed (in Italy at least) to create these educational opportunities, and which require management and administration skills that fall outside the competences of a museum director. Perhaps there is even a certain lack of interest in creating LLL opportunities, despite art being one of the most fitting subjects for this kind of practice in as much as it stimulates a certain "emotional pedagogy". This 
ultimately provides an emotional anchorage that gives guidance throughout the learning experience and allows knowledge and skills to be easily absorbed, even in disciplines other than art and history. The mediated learning environment in museums generates what are referred to as 'alternative skills' - that is, the acquisition of skills through experimentation in different contexts to the school/work environment $[10,19]$ - as well as 'emotional anchorages' $[22,4]$ that facilitate the acquisition and development of metacognitive competences which will, in turn, be useful in day-to-day life. Even in these brief premises we can perceive the intrinsic possibilities of what could emerge from LLL opportunities in museum environments. Museums could offer far more than recreational and leisure-type activities: they could offer educational journeys for the acquisition of specific skills and encourage people to acquire motivational strategies and competences [5,30]. Art thus becomes a medium through which to obtain skills and hence provide people with 'opportunities and tools' [31]. Art ceases to be a mere destination for tourists and curious visitors, but becomes a tool for stimulating continuous education [6]. And higher levels of education are associated with several positive individual and social outcomes. Data collected from past editions of Education at a Glance show that individuals with high educational attainment generally have better health, are more socially engaged, have higher employment rates and are more prone to the acquisition of new knowledge [26, p.10].

An in-depth research carried out on Italian territory has revealed that educational services in museums are somewhat fragmented: there are big discrepancies in human and economic resources, they are disorganise in their communication, though reasonably varied in terms of non-formal learning opportunities [5, 14, 24].

For the mere purpose of comparison let us consider the TATE Modern Gallery, renowned for providing opportunities for learning about art [41] and let us look at the advanced technologies it has on offer. What can be discerned from an on-site investigation is the huge effort put into communication. The TATE dedicates ample space to research on its website and offers a number of projects to schools and adults, in compliance with government objectives [32, 33, p.1-2, 41].

In the light of this appraisal, which serves the purpose of providing an example and is not a comprehensive analysis, we should start to contemplate the relationship between art, new technologies and adult education, and move further into the heart of our investigation.

Given recent research it seems natural to wonder whether technological innovation is thoroughly understood by the public and whether it is perceived as an unmissable opportunity for promoting culture, for propagating knowledge and research, as well as for boosting academic know-how and the acquisition of metacognitive skills. Can the latter contribute to better learning and in what measure? Do advanced technologies help develop specific competences [15] which cannot otherwise be developed? Do they contribute to life-deep learning, that is to the deep learning' $[12$, p.16] that then stimulates interior growth within that person?

The one certainty is that the penetration of new technologies on the cultural scene is one of the priorities that Europe has been pursuing for years. The one area that, in our opinion, could best lend itself to combining technology, skills, metacognitive strategies and lifelong learning is the museum sector, and that is what we will attempt to examine in our research. We know that life-deep learning in an art/museum context could stimulate processes of germination both at a metacognitive level [21] and in terms of self-awareness [39] and help to better prepare individuals for dealing with change, growth and facing life's challenges.

The analyses so far carried show Italy to still be somewhat behind in terms of penetration of advanced technologies [27, 28]. Cultural heritage organisations approach new technologies with great caution. Moreover, virtual tours are often very impersonal and do not respond to the public's need for broadening knowledge. There is much to be done not only in terms of educational offers and the greater involvement of adults in LLL, but also in context of on-site research and experimenting.

Even at a European level research on the knowledge of and learning about art in non-formal contexts, although somewhat more prominent, is not what sparks the most interest. Projects relating to art tend to put greater focus on protection and conservation, rather than promulgating and learning.

On site-research: non-formal learning advanced technologies and art.

Our research does not focus on the technological aspects of the medium used, it does not examine the criteria linked to the development of the software employed, but rather on the dynamics of permanent learning. It is the result of many skills from the different disciplinary sectors of the QUA_SI Interdepartmental Center, which has been investigating these issues for several years. The team involved in on-site research comprises IT experts, psychologists, sociologists, educators and linguists. The research is set within a socio-pedagogical framework and does not presume to be exhaustive but simply to provide information on $\mathrm{AE}$ in non-formal contexts.

Empirical research was structured into 3 different phases, involving 400 subjects:

- (PHASE 1: ON-SITE OBSERVATION and QUESTIONNAIRE, CREATION of the M-ART project) - development of a specific software to carry out on-site research into the ability of visitors to interact with technology; investigation of knowledge acquisition by adults with the support of technology; identification of the 'typical' visitor using direct, on-site observation and a questionnaire. As previously stated we are not looking at the computer engineering aspects, which are not our areas of 
expertise, but exclusively examining aspects linked to LLL;

- (PHASE 2: QUESTIONNAIRE submission on a large scale) submission of a questionnaire to a large spectrum of users between the ages of 16 and 65 , some with connection to the university and others approached randomly at the exit of the Poldi Pezzoli Museum and Palazzo Reale, both located in Milan;

- (PHASE 3: FOCUS GROUP) in-depth analysis of certain crucial aspects of non-formal learning for adults, with particular focus on the emotions stimulated by technology. This in-depth study employs a focus group as its primary research tool.

\section{Phase 1}

In PHASE 1 the educational format on which we based our experience was that of mobile learning. As is common knowledge, mobile learning is different to $e$-learning in that it "is not just electronic, it's mobile" [31] and is seen as its natural evolution. According to Hoppe, Joner, Millard and Sharples [20] "m-learning is e-learning using a mobile device and wireless transmission". On mobile devices, as asserted by Prensky [27] it is possible to learn "almost anything" and mobile devices can provide learning support to pupils of all ages [40]. Mobile learning lends itself perfectly to supporting non-formal learning [3]: that is, people can acquire historical and cultural knowledge directly on-site, either on their own or with the support of a tutor. We employed learning objects (henceforth LO) on tablets, with a monument in Lombardy as the subject of an initial 'demo' that was personalised, user friendly, easy to explore and simple to understand: in short, well suited to non-formal learning. We know that LOs are described in many ways: as pieces of "lego", blocks of educational content, modules or units, but aside from the many different ways of referring to them it should be noted that, whatever the content, there are certain characteristics that distinguish them from any other learning model. In short LOs are:

- units of knowledge with educational objectives;

- contained in size;

- useable and reusable in different contexts (both educational and technological, and hence interoperable);

- easily obtainable through metadata.

To create the LOs used for this experience we considered the guidelines provided by Steinberg [34] and Figg and colleagues [17]. M-ART is an exploration tool for tablets that allows the user to personalise the timeframe and itinerary of his/her visit, as well as the content and the degree of detail desired. It also consents us, the researchers, to track the time, place and manner in which the visit was undertaken, thus identifying a "typical user" and pursuing the goal of significant and highly defined learning [13, p 115]. Through "drag and drop" activities in the work area, different types of content are added to define the usage structure. M-ART thus allows the art piece to be studied and absorbed in a non-formal manner that is entirely different to the experiments proposed to date.

Our on-site research revealed different aspects of the time taken to learn about the art-piece:

- "duration of perception", implying time taken to 'absorb' the art-piece: to observe, study, analyse and understand it. Perception is also iconic because it is precisely by revealing icons and codes that perceiving takes place;

- "duration of narrative", the intrinsic time taken for narrating events that allow us, through "cognitive influence", to recreate the life of a saint, for instance, [1, p. 25-31], by understanding a sequence of events we are able to evoke an image of Saint Francis in the Basilica of Assisi;

- "duration of the story evoked", is the actual lifespan of, for example, a saint and could cover decades.

The spatial dimension was also given careful consideration, proving to be important not only for the composition of the pictorial message of the LOs but also from an IT and engineering perspective.

The type of user to involve was also considered at length, eventually opting for a random selection of curious visitors or tourists, rather than experts in the specific subject matter. The reasoning behind this decision stemmed from the consideration that continuous learning should take place in a wide range of unrestricted contexts that are not influenced by a predetermined selection. Analysis was then made on the type of knowledge to impart and this was divided into three distinctive categories:

- "inventory-type information" on the work of art: facts and figures, historical information, state of preservation, dates of any conservation work carried out, relative photographic material;

- "documentary or scientific-type information": scientific descriptions of objects/works of art, scientific data, particular scientific observations, photographic material of specific scientific interest;

- "generic information": broad description of the art piece, its history, interesting anecdotes, general photographic material suited to a wide range of non-expert observers such as those approached for this project.

In so doing the aim was to move art education away from the traditional school or university academic approach, and make it part of everyday life, a form of expression for mankind and an opportunity for lifelong learning.

The prototype was initially tested on a sample group, during an on-site visit. A questionnaire was then submitted in order to gather information that would help improve and refine the content. The sample group comprised 50 subjects of whom 46 were women and 4 were men, aged between 22 and 34 years. Educational backgrounds included psychological-pedagogical (27\%), linguistic (23\%) and 
technical (50\%). $47 \%$ of the group had acquired history of art notions from school and 53\% through passion and curiosity. The majority of interviewees were more inclined to use traditional audio-guides, rather than mobile or multi-media devices, although $50 \%$ of subjects declared to own a tablet.

Analysis of data collected shows that the "sample group" encountered no particular problems using the M-ART guide created specifically to promote continuous learning. In fact $84 \%$ stated it is was easy to use, $90 \%$ stated that the icons on the interface were comprehensive and intuitive, $88 \%$ considered the content simple and only $10 \%$ encountered some difficulties in using the software. The background audio commentary was considered adequate by $88 \%$ and the guide nearly always met expectations for $54 \%$ of those interviewed. The organisation of content was clear for $25 \%$, and the quality of information sufficient for $34 \%$. For $67 \%$ of the sample group the content (expressed in the LOs) respected criteria for conciseness. The experience was considered "informative" by the majority, but also "educational" by $23 \%$ of the group who appreciated the value of learning in a non-formal context [16].

In short, after undertaking this experiment it emerged from PHASE 1 that:

- knowledge of the work of art increased;

- observation of detail was more appreciated;

- quantity of information and its accessibility served as a stimulus for continuous learning;

- technology used seemed to be well received by the entire group and integration with technology improved the cultural and artistic experience.

From this on-site experience, it emerges that the overall integration between technology and artistic content is not only promising but also has the potential of being developed for a younger audience. Given the small number of participants, the value of this analysis remained purely indicative but nonetheless offered a starting point for subsequent phases of our research, such as content to be included in the questionnaire.

\section{Phase 2}

The questionnaire comprised 56 questions that investigated the following aspects:

- GENERAL INFO: number of exhibitions visited, preference for visiting museums unaccompanied....

- EXHIBITION DESIGN: the predominance of a certain colour, a particular type of lighting...

- CONTENT: specific information about the exhibition visited, the theme, the curatorship...

- LOGISTICS and SERVICES: the provision of catering services, cafés, signposting...

- TECHNOLOGICAL: the provision of advanced technological services within the exhibition, basic Internet access...
The questionnaire was distributed on various occasions over the course of 2013 in the following locations: at a university and in proximity of two Milanese museums, namely the Palazzo Reale and the Poldi Pezzoli, for an overall total of 330 subjects interviewed.

The results were then extracted and interpreted using SPSS (Statistical Package of Social Science). The sample group that the questionnaire was submitted to ranged from 14 to 64 years of age with $38 \%$ aged $22-23$, and an overall $65 \%$ of the group aged between 19-23. The rest of the group was distributed equally between the ages of 24 and 64 . The sample group cannot be considered equally homogenous in terms of gender: males comprise $26 \%$ and females $74 \%$ : $92 \%$ did not specify the subject of their bachelor degree, whereas $18 \%$ of the group stated to be studying for a degree in humanities (law, learning and developmental sciences, education sciences, psychology), and $10 \%$ stated to have already graduated. Furthermore the sample group indicated the following types of employment: services $26 \%$; commerce $9 \%$; education $10 \%$; various types of temp work $4.7 \%$. The remaining 50\% (approx.) did not answer the question. The hundreds of pieces of information gathered provided an overview of which museums are most visited, which European museums are the most technologically appealing, which provide the best workshop environments, etc.

After a comprehensive analysis of the sample group in terms of age, level of education and occupation, then crosschecking these details with information from a control group - obtained by involving a random selection of visitors consulted outside various Milanese museums - it is possible to pinpoint 3 STYLES of approach to continuous learning.

One STYLE, which for the sake of argument we will call INSTINCTIVE EMOTIONAL, is dictated by the innate enthusiasm that guides a subject during his/her visit and identifies the highpoint of an artistic experience as the emotional one. We then have the REFLECTIVE INQUIRING STYLE, where the key characteristic is freedom of thought and where the museum visit represents an opportunity for increasing knowledge; lastly we identified an INTELLECTUAL STYLE, typical of enthusiasts in the subject matter who perceive the artistic experience as an opportunity for learning and personal growth. The non-formal learning experience in the museum environment evokes the following attributes (listed from highest to lowest):

- interesting;

- emotional;

- fascinating;

- educational.

To evaluate the technological aspects it was presumed that the sample group comprised both a "low-tech" segment and a "high-tech" segment. We firstly established that $96 \%$ of the group uses a mobile phone "several times a day", that tablets are used by $27 \%$ of the group "at least once a day", that internet is used by $69 \%$ "several times a day", and by $20 \%$ 
"once a day"; 43\% stated that technology provides "considerable" help for learning about art, 24.1\% states it provides "reasonable" help and the remainder was distributed between $20 \%$ who believe it helps "immensely" and $11 \%$ who remain sceptical about the help that advanced technologies can provide, therefore selecting the options "little" or "not at all". The "high-tech" segment has faith in advanced technologies and makes frequent use of them, whereas the "low-tech" segment prefers a more limited use of technology.

To summarise, it can be said that the overall opinion of new technologies is positive both for the "low-tech" group and the "high-tech" group; additionally, the latter express enthusiasm for the role that technology can have in facilitating museum visits, stimulating the learning process and aiding the study of art.

From the analysis it appears that the "high-tech" segment lament the lack of availability in museums of technological services and other advanced technologies suitable for tablets or smartphones.

\section{Phase 3}

From phase 2 of the research (questionnaire) a number of signs emerged that stimulated further relevant investigation:

- the "inner needs and motivations" that drive people to visit a museum or an exhibition;

- the "emotions" that are felt and expected in an artistic environment;

- the "social dimension" that learning in a museum environment can offer;

- the "learning dimension and the role" that a museum can have for the visitor;

- the "guidance and information" services mediated by technology.

This investigation was carried out through 2 FOCUS GROUPS, each formed by 10 participants who were approached in two different moments of the on-site research that took place this year. From these it emerged that:

- the REASONS for choosing to pursue continuous learning and museum exploration, fluctuate between "the fame of the artist", the "artistic appeal of the place" in which the museum or exhibition is located, and the "contained cost";

- the PERCEPTION of the "role the museum holds, as well as its social dimension" in relation to local territory, appears to be a very important factor to those interviewed;

- the INFORMATION pertaining to "guidance services" are only marginally developed. Aside from two interviewees who stated to have encountered touchscreens and material that could be downloaded via Bluetooth, the others declared to have almost invariably found nothing more than "minimal information" or "traditional audio guides" available in museums or other structures dedicated to artistic and cultural heritage;

- the LEARNING EXPERIENCE THAT CONTINUES throughout ADULTHOOD by providing "advanced services" is not yet present in the majority of Italian museums, just as the matter of LLL using technology is only marginally - or not at all - addressed by cultural and artistic institutions. The subjects declare a total - or almost total - lack of 'awareness' in this sense, despite the fact that the richness and diversity of cultural heritage present on the territory would be, in terms of LLL, highly "suitable" for the pursuit of experimental initiatives or on-site research.

What also emerges is the demand to have information that is "clear, simple and pleasantly mediated" by information technology, in view of pursuing LLL in a non-formal context.

\section{Conclusions}

In conclusion we can see that the importance of the certain aspects has emerged, even in this last phase of research, highlighting the need to:

- "redefine the roles and responsibilities of museums, naturally geared towards the diffusion of artistic and cultural heritage;

- "financially restructure and rearrange" Italian museums so they may effectively compete with the cultural offer provided by other museums in Europe and the world, also considering the creation of special initiatives in context of adult education;

- adopt "advanced services" dedicated to an increasingly technological audience attracted by the "different explorative possibilities" that are ensured by the use of technology (e.g. exploring details that would otherwise be invisible, in-depth information that can be personalised on-site) with a clearly manifested and considerably diffused "trust" in technology in general;

- renew the "educational function" of museums for re-launching Italian artistic and cultural heritage so as to reach the goal of "significant learning" [12]: that is, knowledge that can be effectively applied in a real context - not mere superficial notions to be repeated in intellectual settings - using an approach that pursues the aim of "learning naturally" and in a personalised way (ibidem).

Although our research was not aimed at these learning processes, we have tried to keep in mind both the "natural dimension" - that is, the natural context of daily life within which we are continually learning in informal and in non-formal contexts, even in adulthood - and the "significant dimension" - that is, a dimension linked to emotions generated by artistic content which, by its very nature and in 
a very natural way, stirs emotions and stimulates learning. We have also tried to keep a third dimension in mind: the more personalised "individual dimension" which has become increasingly more researched and examined in pedagogical learning $[9,6,38,18]$.

\section{REFERENCES}

[1] Appiano A. Dentro L'arte. Indagini sulla pittura. Torino: Ananke Edizioni. 2004.

[2] Argenton A. Arte e cognizione. Introduzione alla psicologia dell'arte. Milano: Raffaello Cortina Editore. 2000.

[3] Attewell J. Mobile Learning and Social Inclusion: focusing learners and learning. In Savill-Smith C. (Ed.). Learning with mobile devices: Research and development. UK: LSDA. Retrieved from website: http://www.m-learning.org/docs/Le arning\%20with $\% 20$ Mobile $\% 20$ Devices $\% 20-\% 20$ A $\% 20$ Boo $\mathrm{k} \% 20$ of\%20Papers\%20from\%20MLEARN\%202003.pdf. 2004.

[4] Baldacci M. Curriculo e competenze. Milano: Mondadori. 2010.

[5] Barbaro F. Il museo insegna. L'esperienza didattica alla GAM. Torino: Edizioni GAM. 2002.

[6] Bruner J. La cultura dell'educazione. Milano: Feltrinelli. 2002.

[7] Castells M. The Rise of the Network Society. The Information Age: Economy, Society and Culture. Malden: Blackwell Publisher. 2000.

[8] Castells M. La nascita della società in rete. Università Bocconi Editore. Milano. 2008.

[9] Claparède E. La scuola su misura, Firenze: La Nuova Italia. 1952.

[10] Cormier S.M. In Hangman J.D. (Ed.) Transfer of Learning contemporary research and application. New York: Academic Press. 1987.

[11] Dewey J. Art as Experience. USA: Penguin Gruop. 2005.

[12] Dozza L. (Ed.) Vivere e crescere nella comunicazione. Educazione Permanente nei differenti contesti ed età della vita. Milano: Franco Angeli. 2012.

[13] Dozza L. Chianese G. (Eds.) Una società a misura di apprendimento. Educazione Permanente tra teoria e pratiche. Milano: Franco Angeli. 2012.

[14] Eco R. A scuola con il museo. Guida alla didattica artistica. Milano: Bompiani. 1986.

[15] Ferri P. E-LEARNING. Didattica, comunicazione e tecnologie digitali. Firenze: Le Monnier Università. 2005.

[16] Field I. Lifelong Learning. In Rubenson K. (Ed.) Adult Learning and Education. Oxford: Academic Press: pp. 20-25. 2010.

[17] Figg, C. Burston J. PDA Strategies for Preservice Teacher Technology Training. Proceeding of the 14th World
Conference on Educational Multimedia. Hypermedia and Telecommunications. Denver CO USA. 2002.

[18] Hargreaves A. Lieberman A. Fullan M. \& Hopkins D. Second International Handbook of Educational Change. Dordrecht: Springer. 2010.

[19] Haskell R.E. Transfer of Learning: Cognition Instruction and Reasoning. San Diego: Academic Press. 2001

[20] Hoppe H. U. Joiner R. Milrad M. \& Sharples M. Wireless and mobile technologies in education. JCAL-Journal of Computer Assisted Learning. 19.3. Retrieved from JCAL: http://www.lancaster.ac.uk/users/ktru/ditorial.htm\#ed193. 2003.

[21] Hopper - Greenhill E. The educational role of museum. London: Routledge. 1994.

[22] Järvelä S. Niemivirta M. Motivation in Context: Challenges and Possibilities in Studying the Role of Motivation in New Pedagogical Cultures. In Volet S. Järvelä S. (Ed) Motivation in Learning Contexts. Theoretical Advances and Methodological Implication. Amsterdam: Pergamon: 105-126. 2001.

[23] Johnson M. How to deliver Effective Instruction and Overcome Barriers to Learning in Adult Learners and Technology. UMSL. Retrieved from http://www.camimenko. com/portfolio/found/AdultLearnersAndTechnology.pdf

[24] Munari, B. Fantasia. Roma: Edizioni Laterza. 2003.

[25] OECD. Organization for Economy Co-operation and Development, Education at a Glance, 2014. Retrieved from OECD: http://www.oecd-ilibrary.org /education/ education-a t-a-glance-2014_eag-2014-en

[26] OECD. Organization for Economy Co-operation and Development, Education at a Glance, 2015.Interim Report. Retrieved from OECD: http://www.oecd.org/education/eag-i nterim-report.htm

[27] Prensky M. What can you learn from cell phone? Almost anything! Retrieved from: Innovate: http://innovateonline.inf o/pdf/vollissue 5/WhatCanYou

Learn_from_a_Cell_Phone_Almost_Anything!.pdf. 2004.

[28] Prensky M. From Digital Natives to Digitals Wisdom: Hopeful Essays for $21^{\circ}$ Century Education. Thousand Oaks: Corwin Press. Retrivied from: http://marcprensky.com/writing/Prens ky-Intro_to_From_DN_to_DW.pdf 2012.

[29] Read H. Education trough art. New York: Pantheon Books. 1949.

[30] Rychen D.S. Salganik L.H. Agire le competenze chiave. Scenari e strategie per il benessere consapevole. Milano: Franco Angeli. 2007

[31] Sheperd C. M is for Maybe. Mendeley. Retrieved from TACTIX: http://www.fastrak-consulting.co.uk/tactix/. 2001.

[32] Scartabelli T. Media e Didattica museale. Nuove tecnologie per educare: quando la multimedialità e interattività incontrano il museo e il patrimomio culturale. Raleigh, NC: Lulu.com.2014.

[33] Hacker M. Gordon A. de Vries M. (Eds.) Integrating Advanced Technology into technology education. NATO 
ASI series: Springer-Verlag: Proceedings of the NATO, 1990,9-12 October. Netherlands.

[34] Steinberg, C. Wireless meets wireline e-learning. Proceedings of the $14^{\text {th }}$ World Conference on Educational Multimedia. Hypermedia and Telecommunication. Denver CO USA 2002.

[35] Stern A. I bambini senza età. Milano: Luni Editrice. 1996.

[36] Tallon L. Walker K. (Eds.) Digital Technologies and the Museum Experience. HandHeld Guides and Other Media. Plymouth: AltaMira Press. 2008.

[37] Vavoula G. Towords a theory of mobile learning. Proceedings of the $4^{\text {th }}$ World Conference on mLearning. 2005, 25-28 October. Cape Town. South Africa. Retrieved from mlear: http//www.mlearn.org.za/papers-full.html.

[38] Vertecchi B. Manuale della valutazione: analisi degli apprendimenti e dei contesti. Milano: Franco Angeli. 2003.

[39] Vygotskij L.S. Pensiero e Linguaggio. Bari: Laterza. 1992.

[40] Zarifis G.K. Gravani M.N (Eds.). Challenging the European Area of Lifelong Learning. A critical response. Thessaloniki Greece: Springer.2014.

[41] Hubard O. Art Museum Education: Facilitating Gallery Experiences. Hampishire: Palgrave Macmillan. 2015

[42] Website: LifeLong Learning Programme [Internet] Available from: http://www.programmallp.it /index.php?id cnt=44. 